\title{
Improved fired clay brick compressive strength by recycling wastes of blacksmiths' workshops
}

\author{
Eman N. Shaqour ${ }^{1 *}$ (D, Aimen H. Abo Alela ${ }^{2}$ and Aiman A. Rsheed ${ }^{3}$
}

\author{
*Correspondence: eman.shaqoor@ \\ nub.edu.eg \\ ${ }^{1}$ Architecture Engineering \\ Department, Faculty of Engineering, \\ Nahda University, Benisuef City, \\ Egypt \\ Full list of author information is \\ available at the end of the article
}

\begin{abstract}
This study investigates the effect of using steel filings from the waste of blacksmiths workshops on the clay bricks mixture to improve the bricks' compressive strength. On the other hand, this process can reduce workshops' waste by recycling it to preserve the resources and achieve sustainability. Adding steel filings to the mixture of red clay bricks was in different proportions by weight $(1 \%, 2 \%, 3 \%$, and $4 \%)$ on prototype bricks produced in a lab. Moreover, it aims to increase the effectiveness of clay bricks used in load-bearing walls, which can be used extensively in economical housing to reduce the cost if its strength increases by utilizing it in the load-bearing walls system instead of skeleton. The experimental approach was adopted to reach conclusions, as it is the appropriate approach suitable for this research. Before and after adding steel filings, many properties were tested, such as dimensions, weight, density, water absorption, and compressive strength. It is observed that on increasing the steel filings ratios by the mixture's weight, the prototypes' compressive strength also increases. The highest percentage of increased compressive strength occurred for the specimen with $3 \%$ steel filings by the mixture's weight is (84\%).
\end{abstract}

Keywords: Load bearing walls, Compressive strength, Physical properties, Material properties, Waste management, Clay bricks, Environmental

\section{Introduction}

The openness of architecture to other sciences has become one of the recent era and technological development requirements, especially communications, building materials science, etc. This study is based on strengthening the role of the architecture engineer in developing building technologies and materials using material science to improve the built environment to reduce resource consumption, reduce construction costs, and reduce energy consumption. Raising the structural efficiency of red brick by adding waste to its components can contribute to reducing the use of resources, enhance the environment, as well as switching to building with load-bearing walls and thus reducing the construction cost. Ancient Egyptians constructed their houses from

(c) The Author(s). 2021 Open Access This article is licensed under a Creative Commons Attribution 4.0 International License, which permits use, sharing, adaptation, distribution and reproduction in any medium or format, as long as you give appropriate credit to the original author(s) and the source, provide a link to the Creative Commons licence, and indicate if changes were made. The images or other third party material in this article are included in the article's Creative Commons licence, unless indicated otherwise in a credit line to the material. If material is not included in the article's Creative Commons licence and your intended use is not permitted by statutory regulation or exceeds the permitted use, you will need to obtain permission directly from the copyright holder. To view a copy of this licence, visit http://creativecommons.org/licenses/by/4.0/. The Creative Commons Public Domain Dedication waiver (http://creativecommons.org/publicdomain/zero/1.0/) applies to the data made available in this article, unless otherwise stated in a credit line to the data. 
mud bricks, which is one of Egypt's oldest industries [1]. Ancient Egyptians manufactured mud bricks by adding plant strew to improve the bricks' strength [2]. It is crucial to improve brick properties because the vernacular architecture is threatened by concrete construction [3]. In Egypt, There are two types of mud used to manufacture bricks: clay, which contains iron and crystal. The second is the types that have organic materials and calcium components [4]. Clay bricks in Egypt are used to build internal and external walls with a particular dimension of $(25 \times 12 \times 6.5 \mathrm{~cm})$ [5]. Some factories produce bricks in other sizes, such as the Singer Automatic Bricks Factory, which produces different types of bricks for decorations, internal partitions, and load-bearing walls. The bricks manufacturing process consists of three steps: clay shaping with water, drying, and firing (baking) [6]. Energy, water, and soil are the main components that contributed to brick production [7].

One of the leading environmental science disciplines is waste management to achieve the economic benefits and sustainability of resources. Waste management technologies tend to reuse and recycle wastes rather than disposal [8]. Fired bricks are considered a common building material that causes depletion of natural resources [9]. In 2012, Egypt generated 89.03 million tons of solid waste, including municipal, agricultural, industrial, hazardous medical, construction and demolition, waterway cleansing, and sludge wastes [10]. The shortage of building material related to the increasing demand has drawn researchers' attention to the use of industrial waste in developing building materials by reusing and recycling processes. This will lead to many positive effects such as resource conservation, reduced waste disposal costs, and environmental improvements. Various industrial wastes affected the physical and mechanical properties of bricks and provided environmental solutions [11]. Many attempts were made to improve bricks properties by adding waste material to modify mixtures of bricks such as wastewater, natural fibers, stone sawing waste, glass waste, fly ash, and steel dust [12].

The sense of the research problem stemmed from several matters:

1. Through extrapolation of the number of solid wastes that are produced and disposed of in landfills,

2. The importance of the clay bricks industry in Egypt, which is widely used in the construction sector in external walls, internal partitions, and load-bearing walls,

3. Clay brick industry needs to be improved, and the characteristics of mixtures changed from the traditional pattern to face the challenges of increasing wastes and the demand for building materials,

4. Finally, many challenges face the clay bricks industry, such as saving resources, improving properties, reducing environmental pollution, and reducing costs production process and energy used.

The study aims to improve bricks compressive strength by adding steel filings from the waste of blacksmiths workshops to the mixture. On the other hand, this process can reduce workshops waste by recycling it to preserve the resources and achieve sustainability. This research highlights the observation of experimental study on the effect of adding steel filings to the mixture of red clay bricks in different proportions (1\% to $4 \%$ by weight) on the physical and mechanical properties. Moreover, it aims to increase the effectiveness of clay bricks used in load-bearing walls, which can be used 
extensively in economical housing to reduce the cost if its strength increases by utilizing it in the load-bearing walls system instead of skeleton.

This research aims to provide solutions and a vision for recycling waste from workshops to improve building material and improve the environment and save resources from depletion.

\section{Literature review}

Many previous studies investigated the use of various types of wastes in manufacturing clay bricks mixtures to enhance different properties. Each study has its different tests to experiment with mechanical and physical properties and the influence of the bricks' waste additives. Moreover, using waste with different proportions to enhance brick properties may contribute to sustainability and natural resource-saving. Moreover, many researchers in different places studied the modification of bricks' properties and the proportions of their components and some additives to obtain some advantages and improve the physical and compressive strength. The studies' objectives varied between improving compressive strength and offering solutions to environmental problems by using some available wastes in modifying brick components. A study investigated the change of clay bricks' composition as a construction material to decrease the thermal conductivity through the external walls to achieve thermal comfort within the internal environment by adding bagasse from palm fruit fiber, sugarcane industry, and paper residue from the paper industry. Many properties were tested, such as weight change, compressive strength, crystalline structure, and temperature change [13]. Clay Bricks are considered the most eco-friendly building material. Thus, researchers are trying to add value to the bricks by exploiting the waste to improve its properties by producing environment clay bricks of value-added Groundnut Shell Ash [14].

A study investigated the necessity of examining the efficiency of employing the mixing of waste materials such as iron filings because it creates environmental problems [15]. The compressive strength of earth bricks depends on many factors such as the soil type and the compaction pressure [16].

Paki produced lightweight bricks by adding crumb rubber-concrete combination to improve the thermal resistance. The experimental observations reveal that compressive and splitting strength conforms to the international standards [17]. A study also investigated bricks' production using laundry wastewater sludge by the extrusion method; mechanical properties were relevant to the Brazilian legislation [18]. A study also investigated the utilization of Toinite in clay bricks as a coloring agent with different proportions. The suitable proportion was found to be 3\% [19]. A study in Egypt investigated using drilling cuts wastes in manufacturing clay bricks which contains oil range from 7 to $12 \%$. The compressive strength test results show that using excavation waste containing $16 \%$ oil and burning the brick at a temperature of $700{ }^{\circ} \mathrm{C}$ produced a brick with a higher compressive

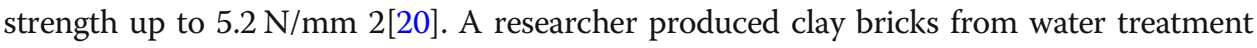
plant sludge. He burned bricks at different temperatures ranges from $\left(900\right.$ to $\left.1150{ }^{\circ} \mathrm{C}\right)$. The value for the compressive strength was $50 \%$ sludge and equals $11.76798 \mathrm{~N} / \mathrm{mm}^{2}$ [21].

\section{Methods}

\section{Research methodology}

To achieve the aims of this study, researchers adopted the experimental approach to reach conclusions, as it is the appropriate approach suitable for this research. This 


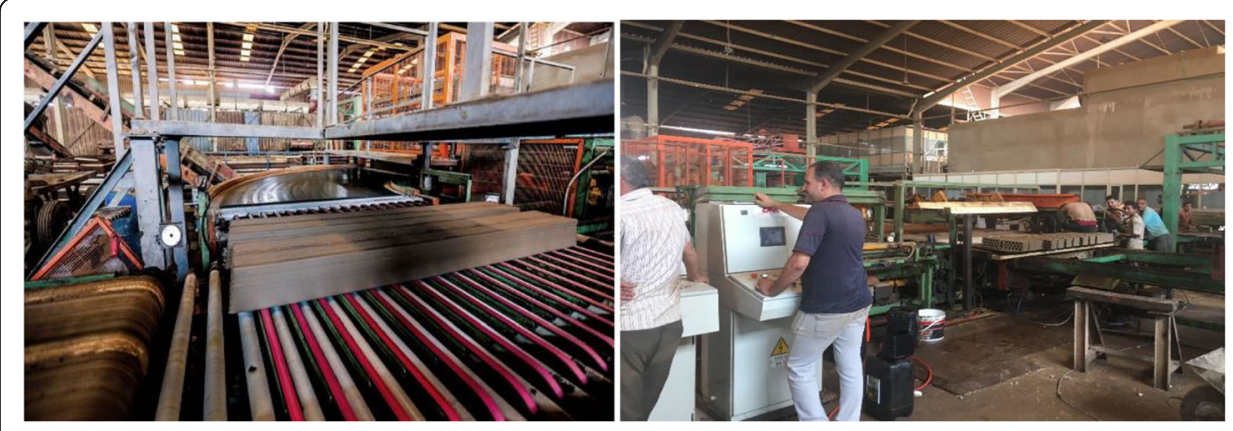

Fig. 1 Pictures inside an automated bricks factory

study consists of an experimental study that evaluates the efficiency of adding steel filings produced from blacksmiths workshops to the manufactured red clay bricks. The efficiency studied is limited to the mechanical properties (the compressive strength) and the physical properties such as water absorption, density, and dimensions.

This study evolved through a set of steps, these are:

1. The research began with a problem definition, then a desk study to explore previous experiments in enhancing clay bricks properties,

2. Then determining the study location, which was in Singer Bricks Factory because it is the only automated brick factory in Egypt that has a laboratory for manufacturing samples and carrying out experiments,

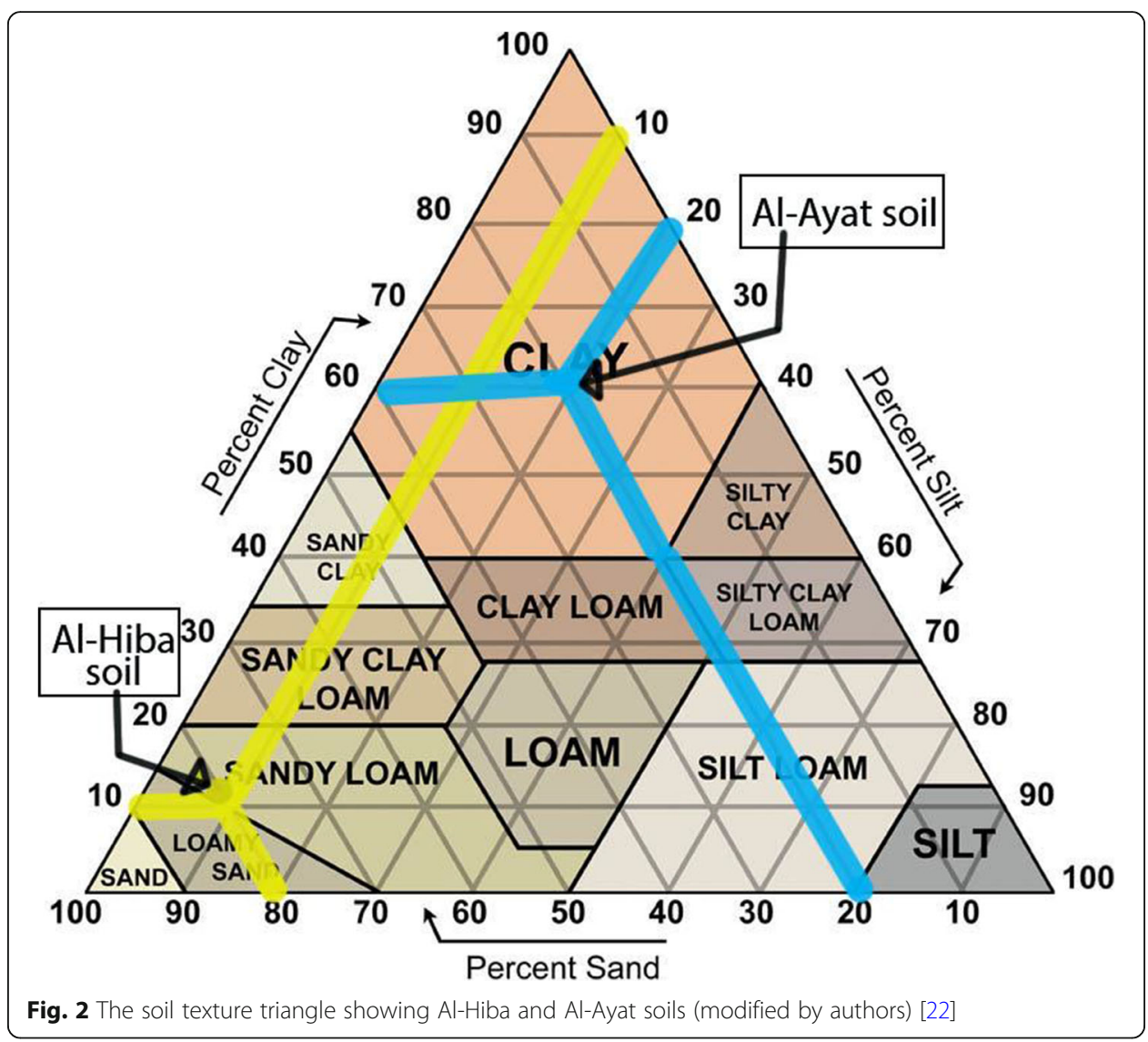




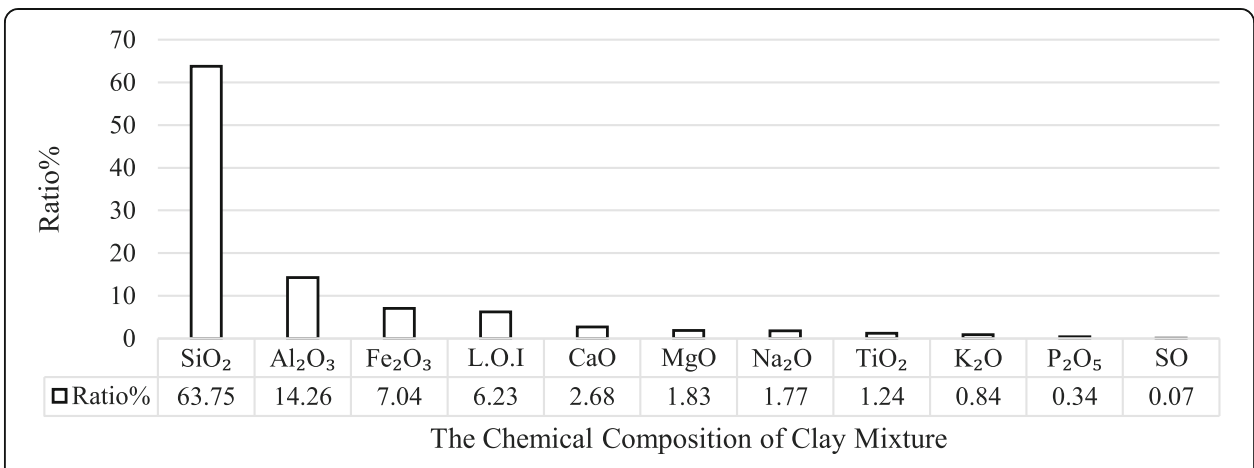

Fig. 3 The chemical composition of 11\% Al-Hiba and 89\% Al-Ayat soils mixture

3. Determine the properties to be studied, which are dimensions, water absorption, and compressive strength,

4. Using Singer Bricks Factory original Mixture to produce prototype bricks,

5. Preparing mixtures with steel filings additive with different ratios $(0 \%, 1 \%, 2 \%, 3 \%$, and $4 \%)$

6. Producing prototype clay bricks inside laboratories using extrusion machine,

7. Drawing and burning the Specimens,

8. Testing the compressive strength and physical properties after 21 days from the manufacturing date to reach the results. The physical properties are average weight, average dimensions, and density.

\section{Preparation of mixtures}

Preparing the prototypes that will be tested using the same mixture used to produce the clay bricks in the automatic factory "Singer Bricks Factory" in Giza Governorate. See Fig. 1.

The factory's mixture ratio for fired bricks to produce the different types of bricks consists of $78 \%$ silt-clay soil and $22 \%$ sand. The silt-clay soil ratio consists of $11 \% \mathrm{Al}$ Hiba soil ( $80 \%$ sand, $10 \%$ silt, and $10 \%$ clay) and $89 \%$ Al-Ayat soil (20\% sand, $20 \%$ silt, and $60 \%$ clay) according to the factory quality control records to reach the required chemical composition. The water percentage is $20-25 \%$ of the total mixture. Figure 2 presents the soil texture triangle showing $\mathrm{Al}-\mathrm{Hiba}$ and $\mathrm{Al}$-Ayat soils.
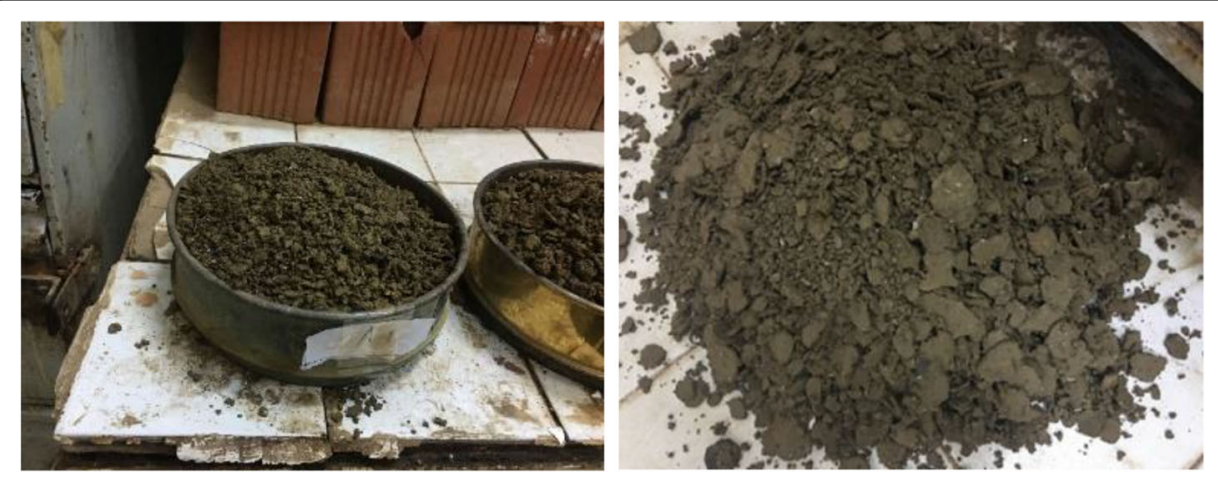

Fig. 4 Clay mixture used to produce prototype bricks 


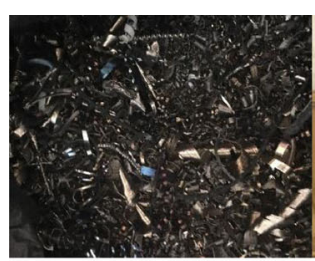

(1) Steel Filings from Blacksmiths Workshops

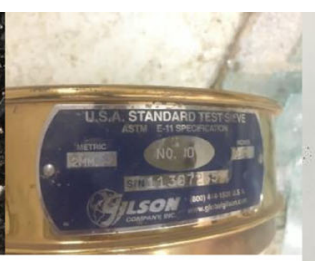

(2) The $2 \mathrm{~mm}$ sieve used for sifting Steel Filings

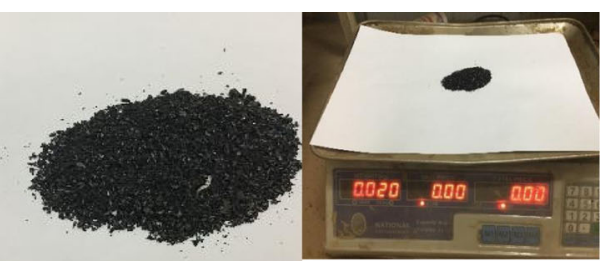

(3) Steel Filings after sifting
(4) Weighing steel filings to add it to the mixture

Fig. 5 Steel filings preparing for the addition

Using an X-ray fluorescence test (XRF) to test the chemical composition of the clay mix used in bricks manufacturing conducted by the factory quality control unit reveals the next result, which are the ratios approved in bricks manufacturing by the factory. Figure 3 shows the chemical composition of the mixture used to produce bricks in the factory.

This mix was used to reach the required chemical composition. The manufacturing process started with moistening the clay with water for 20 days, then the clay is mixed with sand, and the mixture is ground to enter the piston to produce clay bricks. Figure 4 shows the clay mixture after grinding and before it entered the pressing machine to manufacture bricks.

\section{Steel filings additive}

The proportion of metal waste is $2 \%$ of the total waste in Egypt [10]. Recycling iron wastes is essential due to raw material availability. Steel filings used in this experiment were from blacksmiths' workshops' wastes. Iron wastes shapes are powder and chips produced from machines process during iron cutting and shaping. Re-melting iron waste is not an effective process due to energy consumption and gas emissions that has bad effects on the environment, so recycling it in other industries like bricks is more effective [23]. The addition was a percentage of the bricks mixture's weight (1\% to $4 \%$ ), which was prepared for addition to the soil mixture by sieving it with a $2 \mathrm{~mm}$ sieve, the particles smaller than $2 \mathrm{~mm}$ which equals $60 \%$ of the raw wastes, and the rest can be crushed to reach the required size and then used in recycling process. were merged in the manufacturing of bricks. Figure 5 shows the perpetration of the steel filings additive. Figure 5 shows the perpetration of the steel filings additive.

Table 1 Prototype brick dimension

\begin{tabular}{|l|c|c|c|}
\hline & \multicolumn{3}{|c|}{ Dimensions / cm } \\
\hline $\begin{array}{l}\text { The manufactured load-bearing } \\
\text { bricks by the factory }\end{array}$ & 12 & 13 & 25 \\
\hline The prototype dimensions & 2.5 & 2.7 & 5.2 \\
\hline $\begin{array}{l}\text { The ratio of the dimensions of } \\
\text { the original brick to the } \\
\text { manufactured prototype }\end{array}$ & 0.208 & 0.208 & 0.208
\end{tabular}




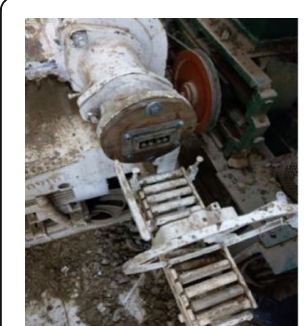

(1)

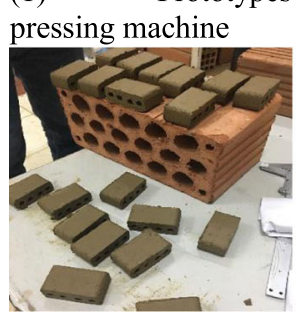

(5) Wet prototypes compared to the original brick

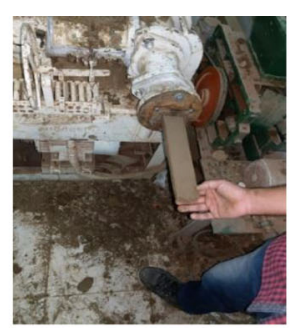

(2) pressing process

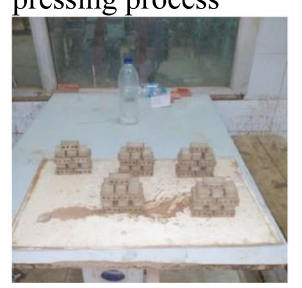

(6) Prototypes after drying from 20-24 hours

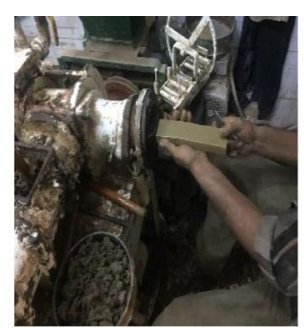

(3) pressing machine

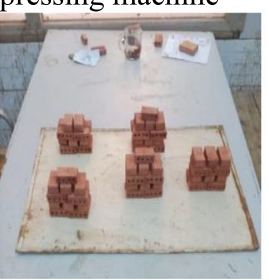

(7) Prototypes after burning for 30 hours

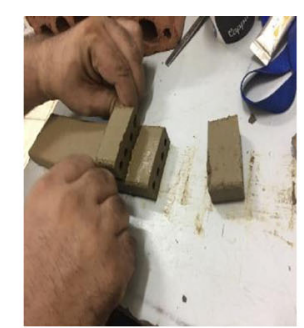

(4) Cutting up the product

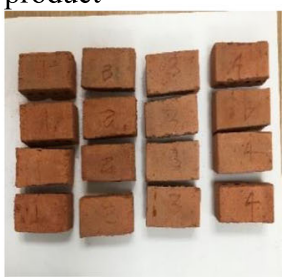

(8) Final Prototypes marked with steel filings ratio

Fig. 6 Bricks prototypes manufacturing process. (1) Prototypes pressing machine. (2) Prototypes pressing process. (3) Prototypes pressing machine. (4) Cutting up the product. (5) Wet prototypes compared to the original brick. (6) Prototypes after drying from 20 to $24 \mathrm{~h}$. (7) Prototypes after burning for $30 \mathrm{~h}$. (8) Final Prototypes marked with steel filings ratio

\section{Clay bricks prototype production}

Bricks used in this study were manufactured from the soil by a lab machine used to produce prototype brick specimens that were used in experiments. In the laboratory, steel filings were mixed with the clay bricks mixture used in Singer Factory to produce bricks. The mixture passed through a pressure and extrusion machine to produce prototypes. The manufactured prototype dimensions are $(2.5 \times 2.7 \times 5.2 \mathrm{~cm})$ as shown in Table 1 .

Five groups of prototype bricks were produced with different ratios of mixing steel filings $(0 \%, 1 \%, 2 \%, 3 \%$, and $4 \%)$ using an in-lab extrusion machine. The laboratory specimen production machines have been adjusted to accommodate the actual bricks manufacturing machines in the factory. The operating settings of the extrusion machine have been set in the laboratory to suit the conditions of the brick-making machines in the factory. The vacuum pump is set to operate at a pressure of -9 to -12 bar to fit the vacuum pressure used in the

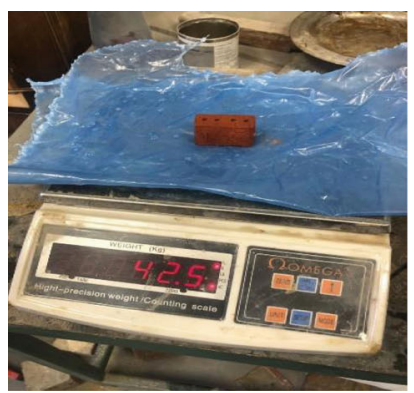

(1) Sensitive electronic balance (weight)

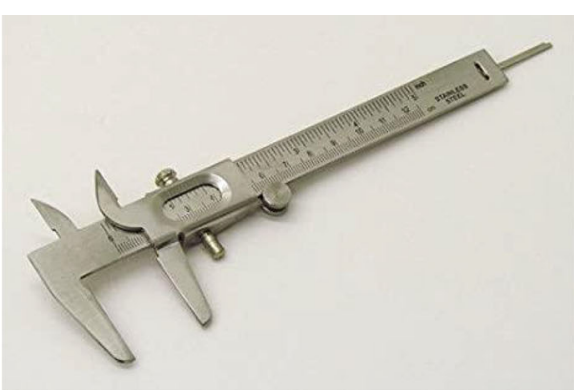

(2) Eisco Labs Vernier Caliper (Dimensions)

Fig. 7 Weight and dimensions measuring tools. (1) Sensitive electronic balance (weight). (2) Eisco Labs Vernier Caliper (dimensions) 

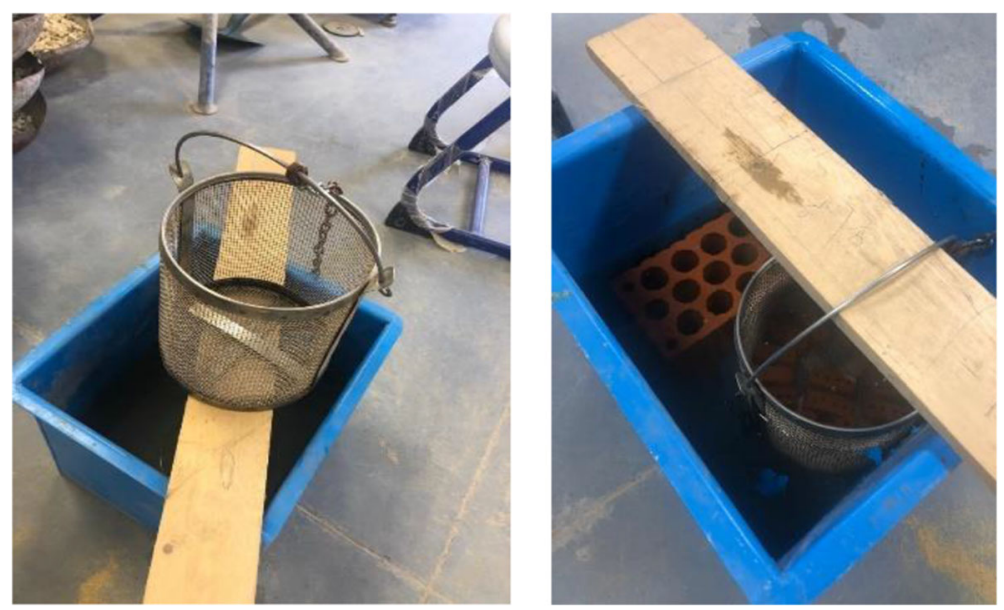

Fig. 8 Water absorption test

factory of 350 bar to deflate air from the specimens, and the air vacuum meter is more than $90 \%$. The manufactured bricks were dried automatically for $20-25 \mathrm{~h}$ inside air dryers containing hot air fans with an air temperature of $100-120^{\circ} \mathrm{C}$. Then, bricks were entered into the factory kilns and remained in the kilns for $30 \mathrm{~h}$; they were burned at a temperature ranging between 800 and $850^{\circ} \mathrm{C}$. Figure 6 clarifies the prototypes' manufacturing process.

\section{Testing the physical and mechanical properties}

Testing the physical properties and the compressive strength were conducted inside laboratories after 21 days from the manufacturing date to reach results. Each compressive strength test was conducted onto five specimen bricks with the same steel fills ratio by weight. At the same time, physical properties tests were conducted on ten specimen's bricks. The test conducted on the prototypes is as follows:

1. The dimensions, weight, and density test using a sensitive electronic balance for weight measuring and the Eisco Labs Vernier Caliper for dimensions as shown in Fig. 4. The dimensions of the prototypes were measured three times, first after manufacturing directly (wet brick), the second stage after removing the brick from the dryer (dry brick), and the third stage after burning the brick (the final shape of the brick). The density was measured after the burning stage. Figure 7 clarifies the measuring tools of dimensions and weight.

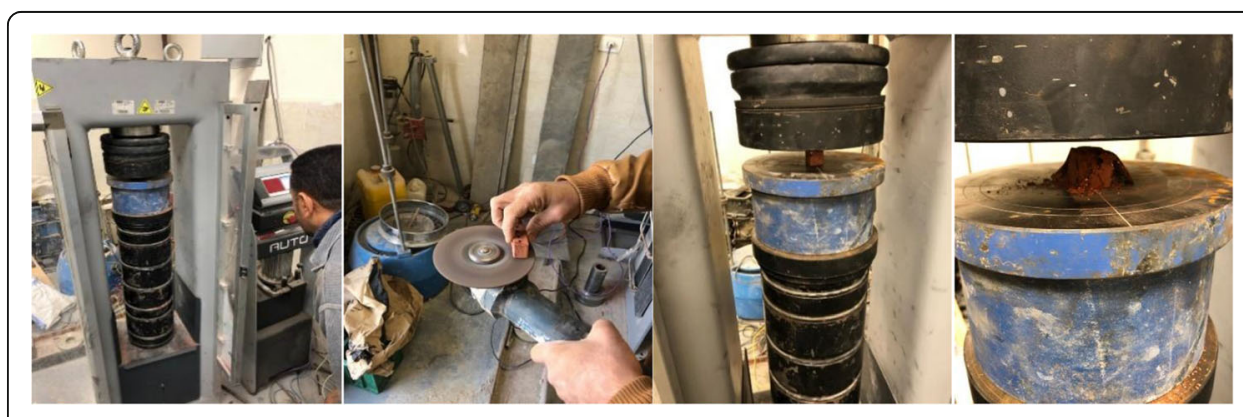

Fig. 9 Universal testing machine (UTM) used to test compressive strength 
Table 2 Results of dimensions, weight, and density tests

\begin{tabular}{|c|c|c|c|c|c|c|c|c|c|c|c|c|c|}
\hline \multirow{3}{*}{$\begin{array}{l}\text { Prototype } \\
\text { Steel } \\
\text { filings\% }\end{array}$} & \multicolumn{4}{|c|}{$\begin{array}{l}\text { Wet case/average of ten } \\
\text { specimens }\end{array}$} & \multicolumn{4}{|c|}{$\begin{array}{l}\text { Dry case/average of ten } \\
\text { specimens }\end{array}$} & \multicolumn{4}{|c|}{$\begin{array}{l}\text { After burning case/average } \\
\text { of ten specimens }\end{array}$} & \multirow{3}{*}{$\begin{array}{l}\text { Density } \\
\mathrm{gm} / \mathrm{cm}^{3}\end{array}$} \\
\hline & \multirow{2}{*}{$\begin{array}{l}\text { Weight } \\
\text { gm }\end{array}$} & \multicolumn{3}{|c|}{ Dimensions $\mathrm{cm}$} & \multirow{2}{*}{$\begin{array}{l}\text { Weight } \\
\text { gm }\end{array}$} & \multicolumn{3}{|c|}{ Dimensions cm } & \multirow{2}{*}{$\begin{array}{l}\text { Weight } \\
\text { gm }\end{array}$} & \multicolumn{3}{|c|}{ Dimensions cm } & \\
\hline & & $\mathrm{H}$ & w & L & & $\mathrm{H}$ & w & $\mathbf{L}$ & & $\mathrm{H}$ & w & $\mathbf{L}$ & \\
\hline $0 \%$ & 61 & 2.40 & 3.0 & 5.40 & 45 & 2.25 & 2.80 & 5.20 & 42 & 2.20 & 2.75 & 5.10 & 1.361 \\
\hline $1 \%$ & 61.5 & 2.40 & 3.0 & 5.40 & 46 & 2.25 & 2.80 & 5.20 & 44 & 2.20 & 2.80 & 5.20 & 1.374 \\
\hline $2 \%$ & 62 & 2.40 & 3.0 & 5.43 & 47 & 2.25 & 2.85 & 5.25 & 45 & 2.20 & 2.80 & 5.20 & 1.405 \\
\hline $3 \%$ & 63 & 2.40 & 3.0 & 5.41 & 48 & 2.30 & 2.85 & 5.25 & 47 & 2.25 & 2.85 & 5.20 & 1.410 \\
\hline $4 \%$ & 63.5 & 2.40 & 3.0 & 5.40 & 49 & 2.30 & 2.85 & 5.25 & 48 & 2.25 & 2.85 & 5.25 & 1.426 \\
\hline
\end{tabular}

2. The water absorption test: the bricks were weighted after the manufacturing process was ended to obtain the dry bricks' average masses. In the next step, bricks were submerged in a water tank for $24 \mathrm{~h}$, as shown in Fig. 8 . Then, bricks were picked up from the water, and their surfaces were dried with a piece of cloth. Then, bricks were weighted again to compare with the weight of the dry bricks. The values are calculated according to the next equation.

$$
\mathrm{A}=\frac{\mathrm{M} 2-\mathrm{M} 1}{\mathrm{M} 1} \times 100 \%
$$

where A: the percentage of bricks water absorption

M1: weight of dray specimen

M2: weight of wet specimen after $24 \mathrm{~h}$ in water

3. Compressive strength test: the prototypes were placed on the universal testing machine's loading platform center, as shown in Fig. 4. They were tested under pure compression.

Compressive strength $=\frac{\text { Maximun Load at Failure }}{\text { Average area at bed face }}$

Table 3 Results of water absorption test

\begin{tabular}{lllll}
\hline $\begin{array}{l}\text { Iron filings } \\
\text { \% by weight }\end{array}$ & $\begin{array}{l}\text { Dry bricks weight } \\
\text { Gram }\end{array}$ & $\begin{array}{l}\text { Weight after } \mathbf{1} \mathbf{h} \\
\text { Gram }\end{array}$ & $\begin{array}{l}\text { Weight after } \mathbf{2 4 \mathbf { h }} \\
\text { Gram }\end{array}$ & $\begin{array}{l}\text { The water } \\
\text { absorption } \\
\text { percentage }\end{array}$ \\
\hline $0 \%$ & 42 & 46 & 47 & $11.9 \%$ \\
$1 \%$ & 44 & 48 & 49 & $11.4 \%$ \\
$2 \%$ & 45 & 48.5 & 49.5 & $10.0 \%$ \\
$3 \%$ & 47 & 50.5 & 51.5 & $9.6 \%$ \\
$4 \%$ & 48 & 52.5 & $9.4 \%$ \\
& Limits of ECP 204 (Average of five bricks) & & up to 16\% \\
\hline
\end{tabular}




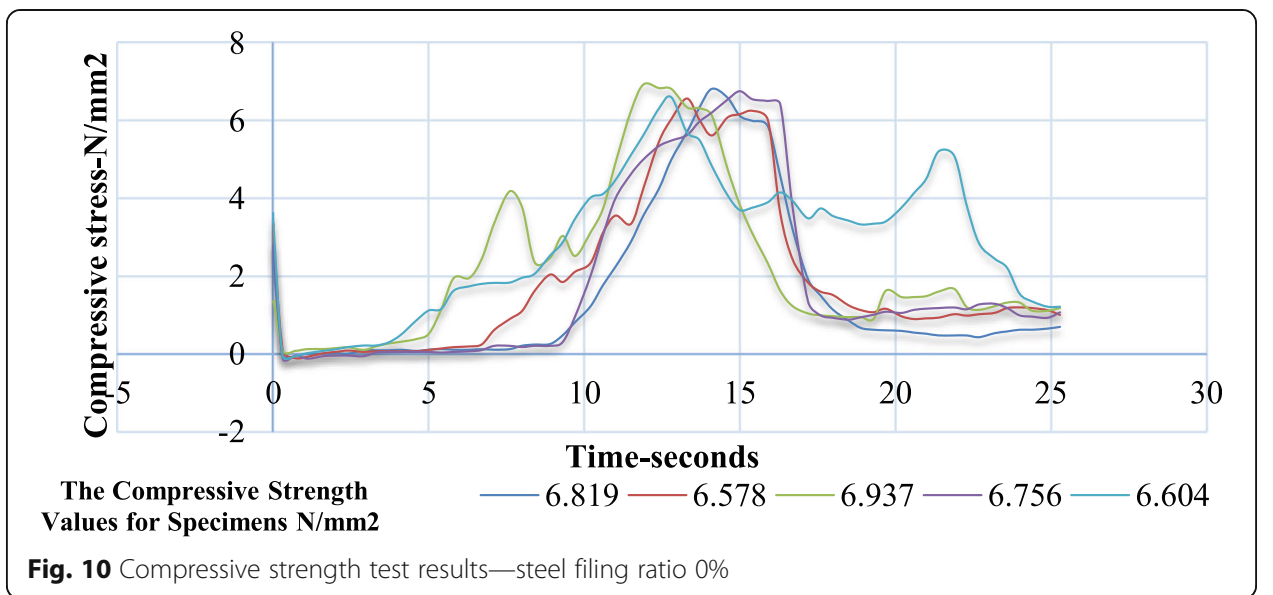

The compressive strength of individual brick shall not fall below the minimum average compressive strength is mentioned in the Egyptian Code of Practice, ECP-204 [24]. Figure 9 shows the compressive strength tests conducted on prototypes in labs.

\section{Results and discussion}

This section of the study illustrates the findings based on the tests conducted in the lab. The results of water absorption, density, and compressive strength were conducted on the specimens with various percentages of steel filings mixed with clay bricks mixture. According to the Egyptian Code of Practice, each test was conducted on five specimens, ECP-204 [24]. The results of tests conducted on various ratios of steel filings mixed with brick mixture are clarified as follows.

\section{Testing the physical properties (dimensions, weight, and density)}

The dimensions and weight of prototypes bricks were measured three times: wet bricks, after drying, after firing. The physical properties (dimensions, weight, and density) tests

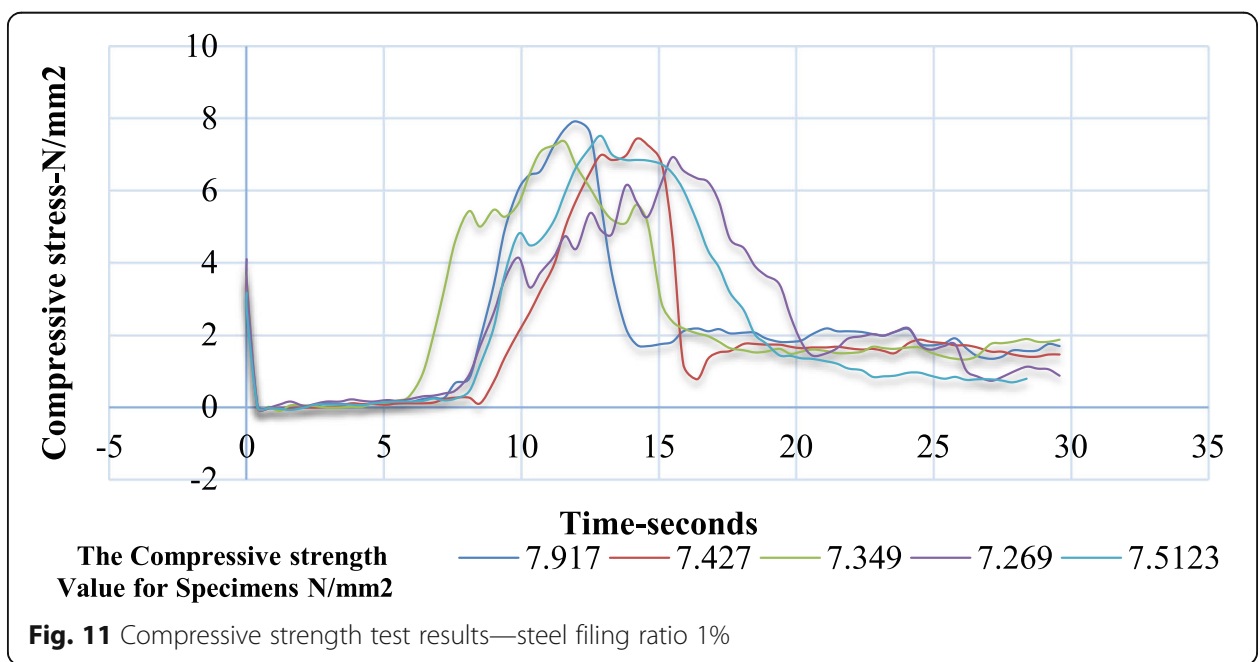




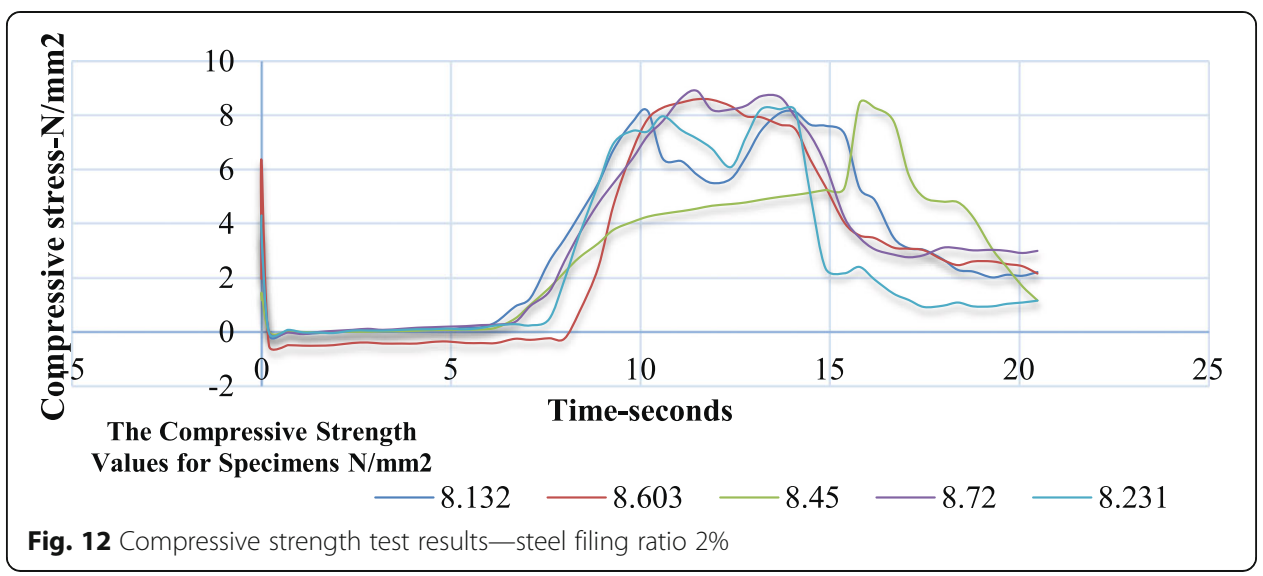

were applied to ten specimens of the same steel filings ratio, and the average was taken for them, as shown in Table 2.

\section{Effect of steel filings ratios on water absorption}

The effect of steel filings ratios on water absorption percentages is represented in Table 3; the results show that the water absorption also decreases with an increase in the percentage of steel filings additive. In general, the water absorption rate is still incompatible with the Egyptian Code of Practice and is less than 16\%. The steel filings brick prototype containing $3 \%$ and $4 \%$ iron gives lesser water absorption values of 9.6 and $9.4 \%$.

\section{Effect of steel filings ratios on compressive strength}

There are different effects on prototypes' compressive strength after adding steel filings compared to the original case ( $0 \%$ steel filings by weight of mixture). Tests on specimens showed that cracks were formed at the top corners of the tested specimens during load increases. Crack length increased to the specimen's base and eventually leads to the final collapse.

From the compressive strength test results, it is evident that $0 \%$ of steel filings give minimum compressive strength of $6.739 \mathrm{~N} / \mathrm{mm}^{2}$, while $3 \%$ of steel filings by weight give

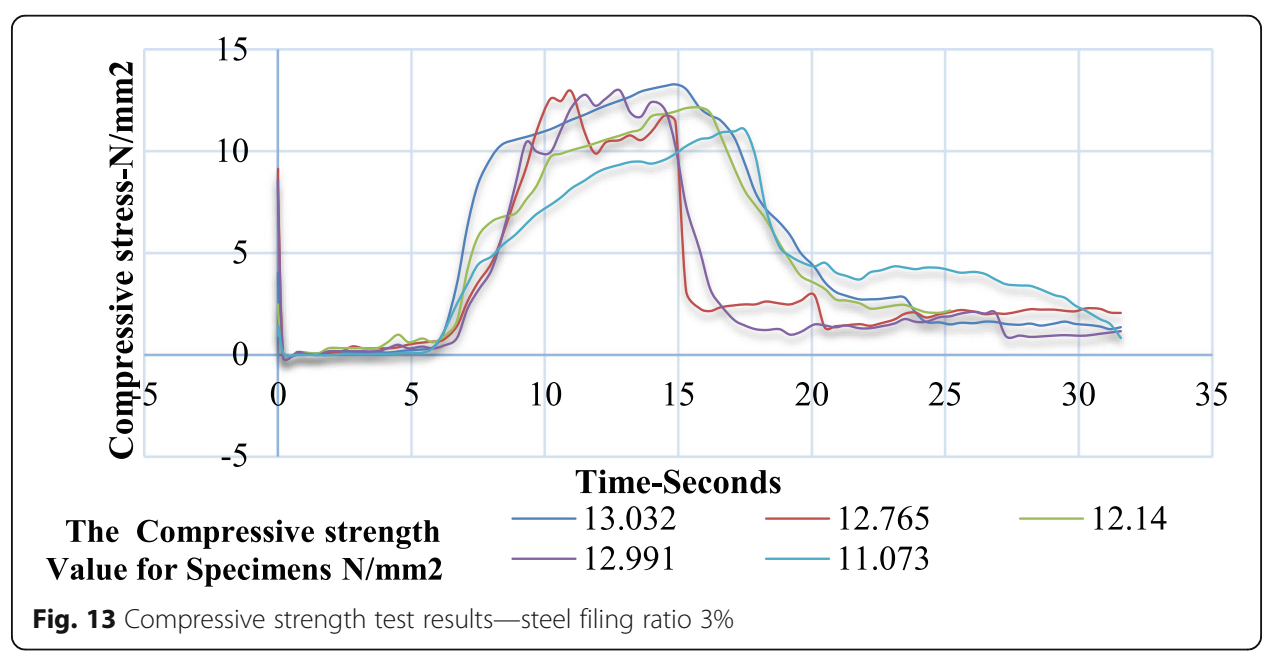




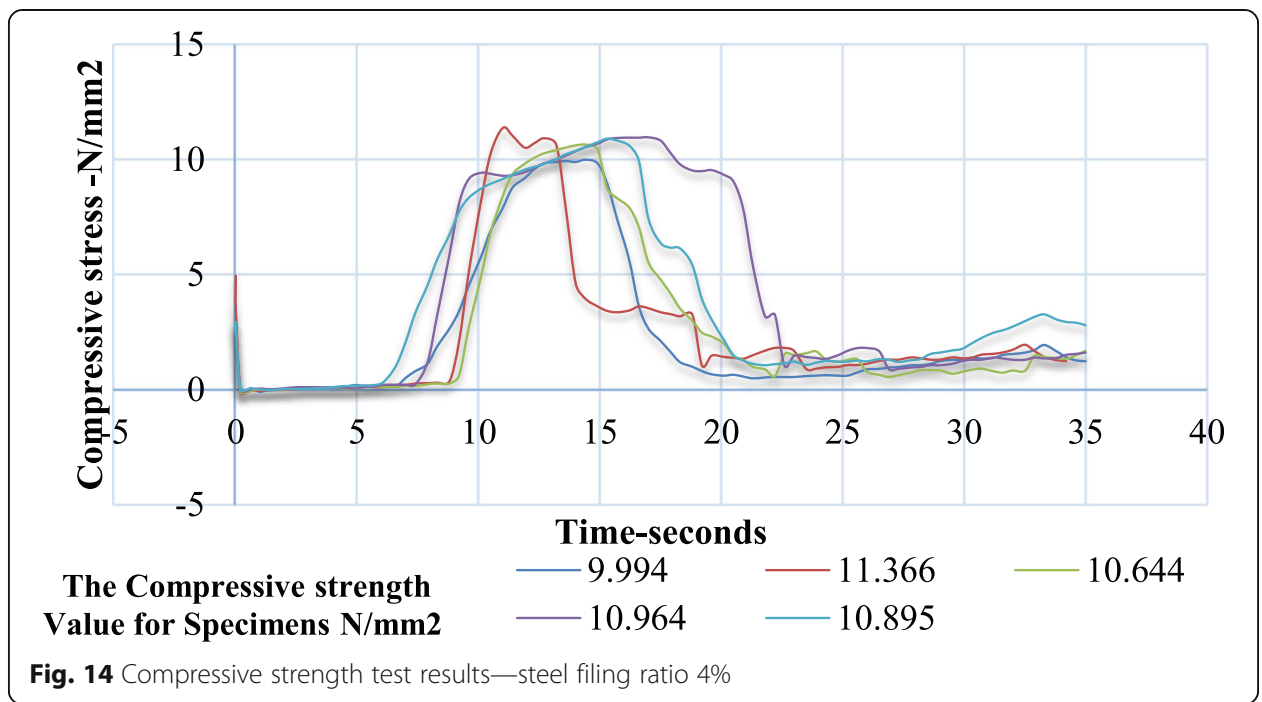

maximum compressive strength of $\left(12.400 \mathrm{~N} / \mathrm{mm}^{2}\right)$. In general, it is observed that on increasing the percentage of steel filings, the compressive strength of prototypes of bricks also increases, but further increase in steel filings (4\% steel filings by weight of mixture) reduces the strength. Figures 10, 11, 12, 13, and 14 present the compressive strength test results conducted on specimens with different steel filings ratios by weight.

The highest percentage of increase in compressive strength occurred for the specimen with $3 \%$ steel filings by weight of the mixture is (84\%), as shown in Fig. 15. Increasing the steel filings ratios over $3 \%$ led to an increase in compressive strength of bricks but by less than the increases resulting from the $3 \%$ compared with the control specimens.

\section{Conclusions}

This study was carried to examine the effect of adding steel filings to fired clay bricks mixture on properties such as density, water absorptions, and compressive strength. The study also explored the benefits of adding wastes of blacksmiths workshops to improve building material to preserve resources. The compressive strength of prototypes

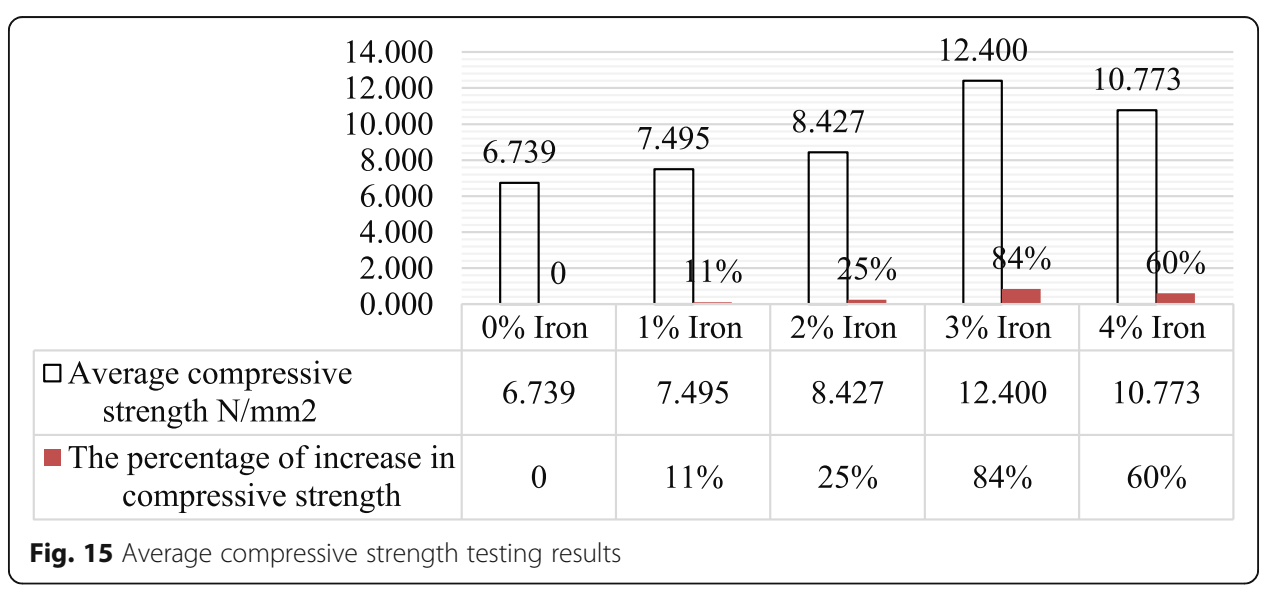


with steel filings by weight of mixture was examined. The content of the prototype mixture was clay, sand, and water. Different steel filings ratios were added to the original brick content by weight to raise the compressive strength. It is observed that on increasing the steel filings ratios by the mixture's weight, the prototypes' compressive strength also increases. The highest percentage of increased compressive strength occurred for the specimen with $3 \%$ steel filings by weight of mixture ( $84 \%)$.

Increasing the compressive strength of the sample can be used by many options:

1. Changing the original mixture's proportions by increasing the ratio of sand and reducing the percentage of silt-clay soil. This contributes to preserving environmental resources and achieving balance.

2. Studies can be done to reduce the width of clay brick while maintaining the established compressive strength incompatible with the Egyptian Code, which contributes to preserving resources.

3. Studies can be made on buildings with load-bearing walls built from clay bricks and study the possibility to improve the properties of these buildings by increasing the number of floors or reducing the wall thickness.

The efficient usage of workshop waste steel filings in clay bricks has many advantages on iron waste recycle, compressive strength of clay bricks, and preserving resources. The water absorption percentage is inversely proportional to the value of iron addition.

Abbreviations

M: Mass; N: Newton; H: Height; W: Width; L: Length

\section{Acknowledgements}

The authors wish to thank Singer automated bricks factory to allow them to use factory's lab to run experiments

\section{Authors' contributions}

The compressive strength for the fired red clay bricks can be doubled when adding 3\% steel filings by weight of mixture to the original mixture. All authors were involved in the different stages of this study. ENS suggested using workshop wastes (iron filings, aluminum filings, wood Sawdust, plastic, car tire waste, glass, etc.) to improve brick properties. AAR supervised the perpetration of samples and controlled the laboratory machines with aid from ENS and AHA. AHA was executing the tests with help from ENS. ENS wrote the manuscript and analyzed the results. All authors read and approved the final manuscript.

Funding

No funding source available.

\section{Availability of data and materials}

The data that support the findings of this study are available from the corresponding author upon reasonable request.

\section{Declarations}

Competing interests

The authors have declared no conflict of interests.

\section{Author details}

${ }^{1}$ Architecture Engineering Department, Faculty of Engineering, Nahda University, Benisuef City, Egypt. ${ }^{2}$ Architecture Engineering Department, Faculty of Engineering, Benisuef University, Benisuef City, Egypt. ${ }^{3}$ Mechanical Engineering, Mechatronics Department, Nahda University, Benisuef City, Egypt.

Received: 9 April 2021 Accepted: 17 June 2021

Published online: 18 August 2021

\section{References}

1. Attalla R, Falana JN, Delany A (2020) The technology of mud-bricks from the sacred architecture in ancient Egypt to the greenhouse revolution case study of Luxor city, Egypt. International Journal of Advanced Science and Technology 29(4 s):1264-1277 
2. Hassaan GA (2017) Mechanical engineering in ancient Egypt, part 52: Mud-Bricks Industry. International Journal of Advanced Research in Management, Architecture, Technology and Engineering 3(7):11-16

3. Gabr AH, Marei MS (2016) Aswan vernacular mud brick architecture as living heritage transmitting traditions. J Eng Appl Sci 63(4):237-255

4. Nagwa AS (2016) Analytical study of archaeological bricks from Coptic period, Dayr Al-Naqlun (the monastery of the angel Ghubriyal), Fayoum, Egypt. Journal of Applied Geology and Geophysics 4(4):30-38. https://doi.org/10.9790/09900404013038

5. Salah M, Awad M, Kamel Y (2018) Sustainable building material technology as an approach to thermal comfort in low income housing in hot regions. Mansoura Engineering Journal 43(2):12-21

6. Sheta S, El Laithy N (2015) Brick kiln industry and workers' chronic respiratory health problems in Mit Ghamr district, Dakahlia governorate. Egyptian Journal of Occupational Medicine 39(1):37-51

7. Dabaieh, M., Heinonen,J., El-Mahdy, D., Hassan, D. M.," A comparative study of life cycle carbon emissions and embodied energy between sun-dried bricks and fired clay bricks", J Clean Prod, Vol. 275, 2020 https://doi.org/10.1016/j.jclepro.202 0.122998

8. Abdelmawla M, Abdelaal A, Beheary MS, Abdullah NA, Razek TMA (2019) Compressive strength of geopolymeric cubes produced from solid wastes of alum industry and drinking water treatment plants. Egypt J Chem 62(12):2331-2340

9. Skinder BM, Pandit AK, Sheikh AQ, Ganai BA (2014) Brick kilns: cause of atmospheric pollution. Journal of Pollution Effects and Control 2(2) https://doi.org/10.4172/2375-4397.1000112

10. Zaki T, Kafafi AG, Boushra M, Gommaa AEM (2013) Annual report for solid waste management in Egypt. New center for Integrated Studies of Land and Environment (NILE), (draft), NSWMP/EEAA/GIZ. Ministry of State for Environmental Affairs

11. Shakir AA, Naganathan S, Bin Mustapha KN (2013) Development of bricks from waste material: a review paper. Aust J Basic Appl Sci 7(8):812-818

12. Chan,C., "Effects of natural fibers inclusion in clay bricks: physic-mechanical properties", Journal of International Journal of Civil and Environmental Engineering, Vol.1, pp. 51-57, 2011

13. Bullibabu K, Abidali M (2018) Development and characterization of fired clay bricks by admixture of bagasse, palm fruit fiber and paper residue. International Journal of Current Engineering and Scientific Research 5(4):505-509

14. Fernando PR, Madushani LAD, Praththana M, Nanayakkara HM (2019) Synthesis and characterization of clay brick using waste groundnut shell ash. Journal of Waste Resources and Recycling 1(1)

15. Rasool DA, Dahham OS, Zulkepli NN (2020) The effect of adding recycled waste on the mechanical properties of concrete. Defect and Diffusion Forum 398:83-89 https://doi.org/10.4028/www.scientific.net/ddf.398.83

16. Yehia S, El-Didamony, and M., Elsayed, T. (2017) Low cost housing in Egypt by using stabilized soil bricks. International Journal of Civil, Mechanical and Energy Science 3(3):154-165 https://doi.org/10.24001/ijcmes.3.3.1

17. Turgut P, Yesilata B (2008) Physico-mechanical and thermal performances of newly developed rubber-added bricks. Journal of Energy and Buildings 40(5):679-688 https://doi.org/10.1016/j.enbuild.2007.05.002

18. Herek LCS, Hori CE, Reis MHM, Mora ND, Tavares CRG, BergamasCo R (2012) Characterization of ceramic bricks incorporated with textile laundry sludge. Journal of Ceramics International 38(2):951-959 https://doi.org/10.1016/j.cera mint.2011.08.015

19. Dondi M, Guarini G, Raimondo M, Zanelli C, Fabbriche DD, Agostini A (2010) Recycling the insoluble residue from titania slag dissolution (tionite) in clay bricks. Journal of Ceramic International 36(8):2461-2467 https://doi.org/10.1016/j.cera mint.2010.08.007

20. Elsersy HH, Ghazal HBG (2010) The use of drilling cuttings waste in the manufacture of clay bricks. J Eng Appl Sci 57(3): 233-256

21. Hegazy BE (2007) Brick making from water treatment plant sludge. J Eng Appl Sci 45(6):599-615

22. Twarakavi NK, Simunek J, Schaap M (2010) Can texture-based classification optimally classify soils with respect to soil hydraulics? Water Resour Res 46(1). https://doi.org/10.1029/2009WR007939

23. Karadag HB, Aslan I (2018) Recycling of waste brass and cast iron chips through metal matrix composite material production- investigation of mechanical properties. American Journal of Engineering Research 7(5):292-304

24. Housing and Building National Research Center, Egyptian Code for Design and Construction of Masonry Works ECP 204-2005, 2005 edition, Cairo, Egypt

\section{Publisher's Note}

Springer Nature remains neutral with regard to jurisdictional claims in published maps and institutional affiliations.

\section{Submit your manuscript to a SpringerOpen ${ }^{\circ}$ journal and benefit from:}

- Convenient online submission

- Rigorous peer review

- Open access: articles freely available online

- High visibility within the field

- Retaining the copyright to your article

Submit your next manuscript at $\mathbf{s p r i n g e r o p e n . c o m ~}$ 